\title{
Purchase Intention of Consumers towards Smart Phones in Thiruvallur District
}

\author{
S. Sangeetha
}

\begin{abstract}
This paper explores the purchase intention of smart phone users. Smart phone plays significant role in the present scenario. Smart phones bring new changes and gives new birth to the society. Now days we cannot imagine the world without smart phones. As per the report in India nearly 30 million smart phone purchases quarterly and it keeps on increasing every year. In India the modern technological development will make a tremendous impact in 2025 and it may promote 700 million Internet users. There is also a scope for telecom market to touch Rs.10 trillion. The government also facilitates WIFI to 5,50,000 villages by March 2019 and planned policies for future India. The government also formed $5 G$ India 2020 Forum to uplift the Indian economy. Smart phone market creates a greater impact on Indian economy and it contributes a major part in Gross Domestic Product. The decision of Indian economy is always cost oriented, wherever reasonable products sell the highest. Smart phone rendering various services through different apps. This apps supports to the consumers for food supply, booking cabs and online shopping. Mostly educated middle class people using these facilities. Recently, smart phone advertisements create greater impact on buying intention of consumers in the market. In olden days mobile advertisements exposed only about the product, but now they are showing the real face of the society. In the present scenario, India is a huge market for smart phones. Manufacturers are aware of consumer's wants and desires. This attitude may bring lot of changes in the smart phone market. Brand image is the most predominant variable which influences the purchase intention of end users to buy the smart phones. Brand loyalty plays secondary role which is also influencing buyers while buying the smart phones. In the olden days smart phone market in India has grown mushrooming and at present the emergence of smart phone market is highly successful and an eye opening to our society.
\end{abstract}

Keywords : Smartphone, Purchase Intention and Consumers.

\section{INTRODUCTION}

The Smartphone is taking the globe by storm. If we examine the mobile advertisements, it conveys much information. In those days mobile advertisements conveyed information only about the product, but in the present scenario smart phone advertisement shows other face of the society with different angle. Now days youth are ridiculing technologically challenged older people those who are not using smart phones. This technology based smart phones having Google Maps which shows directions to people while

Revised Manuscript Received on December 05, 2019.

* Correspondence Author

Dr. S. Sangeetha*, Assistant Professor, Department of Commerce, Pachaiyappa's College, Chennai, India. Email ID: dr.sangeephd@gmail.com travel and they need not ask people to find the way. Smart phones bring new changes and gives new birth to the society. In India the enthusiasm to buy smart phones are increasing today. As per the report in India nearly 30 million smart phone purchases quarterly and it keeps on increasing every year. As per the report of International Data Corporation, the mobile subscriptions in India are expected to rise 1.4 billion by 2021. India has an enormous smart phone market that induces the leading smart phone companies like Apple, Vivo, Oppo and Samsung to keenly watch our market when introduce new features and changes in their mobile products. India is a very popular trading place for smart phones and also manufacturers, sellers and distributors are aware of buyer's needs and desires which will make a greater impact on sales. They go for customer-oriented research in order to better their prospects by boosting their sales. Obviously, next to China, India has over 1.08 billion subscribers and plays second largest tele-communication market in the world. In olden days smart phone market in India has grown mushrooming and at present the emergence of smart phone market is highly successful and an eye opening to our society. Today our economy faces an economic boom by hectic sales in smart phone market. This economic situation gives more contribution to the growth of GDP. India places the fourth largest economy in marketing and consuming the smart phones.

\section{STATEMENT OF THE PROBLEM}

According to statistics, smart phone products have a total value 100 billion and more in India. The market has been carved up by a numbers of brands. Numerous brands pushed into market in India. Indian consumers enjoy enormous freedom to choose their smart phone brands from among those popular brands. However, the reason why consumers stick to a particular brand in the midst of a wide range of choice remains to be studied in detail. The research problem undertaken for study here rests on the non availability of such data. So it is proposed to go into the marketing strategies prevailing in India in consonance with the demand for certain products among consumers. The different brands provide different service, different product outlooks and different prices. Therefore, Indian consumers have a wide choice possibility when choosing a smart phone. In contrast, how the smart phone product enterprises attract consumers and create purchase intention to buy their products still lacks research, and it becomes an imperative to study it. So this research is necessary to attend

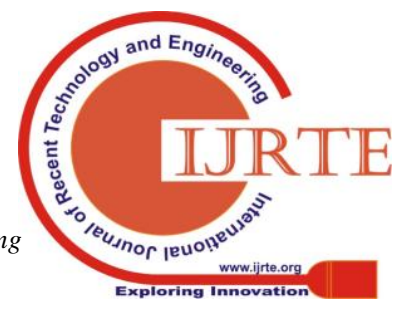




\section{Purchase Intention of Consumers Towards Smart Phones in Thiruvallur District}

the problem of understanding the Indian marketing.

Increasing the high-finish and middle-finish market selling in Indian has become a critical issue that requires resolving. This study exhibits the various factors influencing consumer's purchase intention. It also aims to analyze consumers' satisfaction and purchase intention of consumers with relation to smart phone products. What are the variables affecting the buyers' intention to buy a certain product in an area topographically limited to the Thiruvallur District. In the above cited facts, the researcher has chosen the title "A Study on Purchase Intention of Consumers towards Smart Phone in Thiruvallur District"

\section{OBJECTIVES OF THE STUDY}

1. To analyze the level of satisfaction of consumers with smart phone products.

2. To evaluate the impact of demographic variables on consumer satisfaction and Purchase Intention regarding smart phone products.

\section{LIMITATIONS}

1. The study is confined to four small towns in Thiruvallur District

2. The population is composed of only those consumers' who can afford to buy such smart phones. They belong to above middle class in society.

\section{REVIEW OF LITERATURE}

\begin{tabular}{|c|c|l|}
\hline \multicolumn{1}{|c|}{ Author Name } & Year & \multicolumn{1}{c|}{ Findings } \\
\hline Ling, Chai \&Piew & $\mathbf{2 0 1 0}$ & $\begin{array}{l}\text { They identified purchase intention of undergraduate students in Malaysia. They } \\
\text { find out knowledge about the brand and quality are playing major role in purchase } \\
\text { intention. }\end{array}$ \\
\hline $\begin{array}{l}\text { Anosh Muhammad, } \\
\text { Naqvi Hamad and } \\
\text { Ghulam Shabir }\end{array}$ & $\mathbf{2 0 1 4}$ & $\begin{array}{l}\text { They investigated factors influencing purchase decision of mobile phone devices. } \\
\text { This research reveals that most of the consumers using Samsung smart phones. } \\
\text { Perception, preference, image and loyalty are the important variables taken into the } \\
\text { study. This study finds out all the variables affecting consumers while buying the } \\
\text { product. }\end{array}$ \\
\hline Akar and Nasir & $\mathbf{2 0 1 5}$ & $\begin{array}{l}\text { After reviewing 100 published papers on purchase intention most of the articles } \\
\text { revealed that trust creates positive influence and risk create negative influence on } \\
\text { purchase intention. }\end{array}$ \\
\hline Rex P.Bringula & $\mathbf{2 0 1 8}$ & $\begin{array}{l}\text { This study focused factors influencing on - line purchase intention of smart phones. } \\
\text { Data was collected from students. Company, personal and technical factors are the } \\
\text { factors taken into the study. Trust and Consistency are considered as greater impact } \\
\text { among buyers. }\end{array}$ \\
\hline
\end{tabular}

\section{RESEARCH GAP}

Though adequate research has been done in various aspects of consumer behaviour pattern due to influence on purchase intention it is found no research has been carried especially on smart phone products, that too in the small towns in Thiruvallur District. In this rapidly changing \& overly exposed Indian consumers, it is difficult to keep track of their behavior and satisfaction towards smart phone products \& its impact on purchase intention. It's the most indispensable aspect, what do they perceive \& how do they decide buying in particular smart phone category. This paper therefore is systematically organized \& scientifically analyzed. So the research is concerned about the consumer's buying intention of smart phone in Thiruvallur District.

\section{RESEARCH METHODOLOGY}

1. The researcher has used both primary and secondary data. Questionnaire method was used to collect the primary data.

2. This study was conducted in Thiruvllur District(Avadi, Pattabiram, Thiruninravur and Veppampattu).

3. The researcher has adopted convenience sample of 154 individuals who used smart phones in various towns of Thiruvallur District, Tamil Nadu, India.

\section{A. Statistical Tools Used}

- Percentage analysis

- One-sample t-test

- One way ANOVA

- Bi-Variate Correlation

\section{SUMMARY OF FINDINGS}

\section{Profile of the respondents}

The researcher has collected data from the respondents those who are using smart phones. Personal profile of the respondents consist gender, age, education, occupation, monthly family income, marital status and family type. Table 1 clearly shows that majority of men using smart phones. Most of the salaried and high income people buying smart phones. 
Table 1. Profile of the respondents

\begin{tabular}{|c|c|c|c|c|}
\hline Particulars & Classification & $\begin{array}{c}\text { Number of } \\
\text { Respondents }\end{array}$ & Percentage & Results \\
\hline \multirow{2}{*}{ Gender } & Male & 80 & 51.95 & \multirow{2}{*}{ Majority of the selected respondents $(52.6 \%)$ are male. } \\
\hline & Female & 74 & 48.05 & \\
\hline \multirow{4}{*}{ Age } & Below 25 Years & 47 & 30.52 & \multirow{4}{*}{$\begin{array}{l}\text { Majority of the respondents ( } 39.9 \%) \text { fall in the age group of } \\
\qquad 25-35 \text { years. }\end{array}$} \\
\hline & $25-35$ years & 55 & 35.71 & \\
\hline & $36-45$ years & 35 & 22.73 & \\
\hline & Above 45 years & 17 & 11.04 & \\
\hline \multirow{5}{*}{ Education } & School level & 39 & 25.32 & \multirow{5}{*}{$\begin{array}{l}\text { Half of the respondents }(49.5 \%) \text { using smart phones are } \\
\text { UG/PG graduates. }\end{array}$} \\
\hline & Diploma & 29 & 18.83 & \\
\hline & UG/PG & 58 & 37.66 & \\
\hline & Professional & 20 & 12.99 & \\
\hline & Others & 8 & 5.19 & \\
\hline \multirow{6}{*}{ Occupation } & Salaried Job & 54 & 35.06 & \multirow{6}{*}{$\begin{array}{c}\text { Majority of the respondents }(33.6 \%) \text { using smart phones are } \\
\text { salaried employees. }\end{array}$} \\
\hline & Business/Self-employed & 18 & 11.69 & \\
\hline & Professional & 26 & 16.88 & \\
\hline & Student & 41 & 26.62 & \\
\hline & Home maker & 10 & 6.49 & \\
\hline & Others & 5 & 3.25 & \\
\hline \multirow{4}{*}{ Monthly family Income } & Less than Rs.50,000 & 75 & 48.70 & \multirow{4}{*}{$\begin{array}{l}\text { Most of the respondents' }(70.5 \%) \text { family income per month } \\
\text { is less than Rs.50,000 and they are all using smart phones. }\end{array}$} \\
\hline & Rs. $50,000-1,00,000$ & 52 & 33.77 & \\
\hline & Rs. $1,00,001-2,00,000$ & 18 & 11.69 & \\
\hline & Above Rs.2,00,000 & 9 & 5.84 & \\
\hline \multirow{2}{*}{ Marital status } & Married & 85 & 55.19 & \multirow{2}{*}{ Majority of the consumers using smart phones are married. } \\
\hline & Unmarried & 69 & 44.81 & \\
\hline \multirow{2}{*}{ Family type } & Joint & 87 & 56.49 & \multirow{2}{*}{ Majority of consumer belongs to joint family. } \\
\hline & Nuclear & 67 & 43.51 & \\
\hline
\end{tabular}

Source: Primary data

\section{Smart Phones brands used by the respondents}

Respondents are conveyed information about their smart phone brands. Table. 2 explores that the brands used by the respondents in smart phones.

Table 2: Smart Phones brands used by the respondents

\begin{tabular}{|c|c|c|}
\hline Brand Name & Number of Customers & Percentage \\
\hline Sony & 10 & 6.49 \\
\hline Samsung & 61 & 39.61 \\
\hline Nokia & 22 & 14.29 \\
\hline Lenovo & 46 & 29.87 \\
\hline Others & 15 & 9.74 \\
\hline Total & 154 & 100 \\
\hline
\end{tabular}

Source: Primary data

The above table shows that majority (39.61\%) of consumers using Samsung brand in smart phones.

\section{Purchase Intention On Smart Phone Products}

Perception towards Purchase Intention

$\mathbf{H}_{\mathbf{0}}$ 1: The perception level of the respondents towards Purchase intention does not differ with the average score.

The results of one sample t-test for variables measured for studying the perception of the respondents on Purchase intention towards smart phone products are displayed in the table 3 . 


\section{Purchase Intention of Consumers Towards Smart Phones in Thiruvallur District}

Table 3. One sample t-test for Purchase intention

\begin{tabular}{|l|c|c|c|c|c|}
\hline \multicolumn{1}{|c|}{ Statements } & Mean & SD & t-value & p-value & Result \\
\hline $\begin{array}{l}\text { I would buy the product of this brand rather than any other } \\
\text { brands available }\end{array}$ & 1.98 & 0.231 & $3.452^{* *}$ & $\begin{array}{c}\text { Lower than the } \\
\text { average mean } \\
\text { score }\end{array}$ \\
\hline I intend to purchase the product of this brand in the future & 2.76 & 1.064 & $2.947 * *$ & $<.001$ & $\begin{array}{c}\text { Higher than the } \\
\text { average mean } \\
\text { score }\end{array}$ \\
\hline I actively encourage others to buy the product of this brand & 3.21 & 1.865 & $2.894^{* *}$ & $<.001$ & $\begin{array}{c}\text { Higher than the } \\
\text { average mean } \\
\text { score }\end{array}$ \\
\hline $\begin{array}{l}\text { I would like to buy the product of this brand for others as a } \\
\text { gift }\end{array}$ & 2.45 & 1.004 & $3.657 * *$ & $<.001$ & $\begin{array}{c}\text { Higher than the } \\
\text { average mean } \\
\text { score }\end{array}$ \\
\hline $\begin{array}{l}\text { I will not switch over to other brands even if an alternative } \\
\text { brand offers more promotions or added values }\end{array}$ & 3.73 & 0.962 & $4.237 * *$ & $<.001$ & $\begin{array}{c}\text { Higher than the } \\
\text { average mean } \\
\text { score }\end{array}$ \\
\hline
\end{tabular}

Table 3 states that the respondents perception on purchase intention towards smart phone product in Thiruvallur District. The t-values of the variables: 3.452, 2.947, 2.894, 3.657 and 4.237 significant at $1 \%$ level. The null hypothesis is rejected. This table states that consumers having good buying intention. It also results consumers intend to buy the same brand even the competitor's offers and promoting brand with more added value and benefits.

\section{Influence of respondents' demographic variables on Purchase intention}

To test the significant influence of respondents' demographic variables on Purchase intention one way ANOVA is applied to ascertain the influence of respondent's demographic variables on Purchase intention. The following null hypotheses are framed:
$\mathbf{H}_{0}$ 2: There is no significant influence of respondents' (a) gender (b) age (c) education (d) occupation (e) monthly family income (f) marital status (g) family type on Purchase intention towards Smart Phone products.

Table 4 indicates the results of influence of respondent's demographic variables on Purchase intention towards Smart Phone products in Thiruvallur District.

Table 4: Influence of demographic variables on Purchase intention

\begin{tabular}{|c|c|c|c|c|c|c|}
\hline Variable & Category & $\mathbf{N}$ & Mean & S D & F-value & Result \\
\hline \multirow{2}{*}{ Gender } & Male & 80 & 0.50 & 2.66 & \multirow{2}{*}{$\begin{array}{c}0.101 \\
(\mathrm{p}=.899)\end{array}$} & \multirow{2}{*}{$\begin{array}{l}\text { Insignificant at } 5 \% \text { level.Formulated } \\
\text { hypothesis accepted }\end{array}$} \\
\hline & Female & 74 & 0.44 & 2.65 & & \\
\hline \multirow{3}{*}{ Age } & Below 25 Years & 47 & 0.50 & 2.61 & \multirow{3}{*}{$\begin{array}{c}1.021 \\
(\mathrm{p}=.162)\end{array}$} & \multirow{3}{*}{$\begin{array}{c}\text { Insignificant at } 5 \% \text { level. Formulated } \\
\text { Hypothesis accepted }\end{array}$} \\
\hline & 25-35 years & 55 & 0.43 & 2.72 & & \\
\hline & Above 45 years & 17 & 0.49 & 2.56 & & \\
\hline \multirow{4}{*}{ Education } & School Level & 39 & 0.47 & 2.67 & \multirow{4}{*}{$\begin{array}{l}5.321 * * \\
(\mathrm{p}<.001)\end{array}$} & \multirow{4}{*}{$\begin{array}{l}\text { Significant at } 1 \% \text { level. Formulated } \\
\text { hypothesis rejected. This indicates that the } \\
\text { respondents having other education are } \\
\text { having better purchase intention and the } \\
\text { diploma holders are lacking in purchase } \\
\text { intention. }\end{array}$} \\
\hline & Diploma & 29 & 0.47 & 2.56 & & \\
\hline & UG/PG & 58 & 0.44 & 2.58 & & \\
\hline & Others & 8 & 0.46 & 2.99 & & \\
\hline \multirow{3}{*}{ Occupation } & Salaried Job & 54 & 0.47 & 2.67 & \multirow{3}{*}{$\begin{array}{c}1.022 \\
(\mathrm{p}=.185)\end{array}$} & \multirow{3}{*}{$\begin{array}{l}\text { Insignificant at } 5 \% \text { level. Formulated } \\
\text { hypothesis accepted. }\end{array}$} \\
\hline & Business/Self-employed & 18 & 0.53 & 2.74 & & \\
\hline & Professional & 26 & 0.50 & 2.73 & & \\
\hline
\end{tabular}




\begin{tabular}{|c|c|c|c|c|c|c|}
\hline & Student & 41 & 0.45 & 2.55 & & \\
\hline & Home maker & 10 & 0.41 & 2.67 & & \\
\hline & Others & 5 & 0.35 & 2.56 & & \\
\hline \multirow{4}{*}{$\begin{array}{l}\text { Monthly } \\
\text { Income }\end{array}$} & Less than Rs.50,000 & 75 & 0.46 & 2.61 & \multirow{4}{*}{$\begin{array}{c}2.698 * \\
(\mathrm{p}=.012)\end{array}$} & \multirow{4}{*}{$\begin{array}{c}\text { Significant at } 5 \% \text { level. Formulated } \\
\text { hypothesis rejected. This exposes that the } \\
\text { respondents earning more than Rs.2,00,000 } \\
\text { per month are having better purchase } \\
\text { intention level and the respondents earning } \\
\text { less than Rs. } 50,000 \text { are having lesser } \\
\text { purchase intention. }\end{array}$} \\
\hline & Rs. $50,000-1,00,000$ & 52 & 0.46 & 2.80 & & \\
\hline & Rs. $1,00,001-2,00,000$ & 18 & 0.45 & 2.64 & & \\
\hline & Above Rs.2,00,000 & 9 & 0.62 & 2.82 & & \\
\hline \multirow{2}{*}{ Married Status } & Married & 85 & 0.48 & 2.67 & \multirow{2}{*}{$\begin{array}{c}0.132 \\
(\mathrm{p}=.438)\end{array}$} & \multirow{2}{*}{$\begin{array}{l}\text { Insignificant at } 5 \% \text { level. Formulated } \\
\text { Hypothesis accepted }\end{array}$} \\
\hline & Unmarried & 69 & 0.46 & 2.65 & & \\
\hline \multirow{2}{*}{ Family type } & Joint & 87 & 0.47 & 2.65 & \multirow{2}{*}{$\begin{array}{c}0.268 \\
(\mathrm{p}=.475)\end{array}$} & \multirow{2}{*}{$\begin{array}{l}\text { Not significant at } 5 \% \text { level. Formulated } \\
\text { hypothesis accepted }\end{array}$} \\
\hline & Nuclear & 67 & 0.46 & 2.67 & & \\
\hline
\end{tabular}

* Significant at $5 \%$ level ** Significant at 1\% level

\section{Relationship between Purchase intention and Customer satisfaction towards Smart Phone products}

To find out the significant relationship between Purchase intention and Customer satisfaction towards Smart Phone bi-variate correlation is applied to evaluate the significant relationships between consumer satisfaction and purchase intention. The following null hypotheses were framed:

H03: There is no significant relationship between Customer satisfaction and purchase intention towards Smart Phone products.

Table 5: Correlation analysis for relationship between Purchase intention and Customer satisfaction

\begin{tabular}{|c|c|c|c|}
\hline \multirow{2}{*}{ chase intention } & \multicolumn{2}{|c|}{$\begin{array}{c}\text { Customer } \\
\text { satisfaction }\end{array}$} & \multicolumn{1}{|c|}{ Result } \\
\cline { 2 - 3 } & r-value & p-value & \\
\hline & $<.536^{* *}$ & $<.001$ & $\begin{array}{c}\text { It shows positive relationship. Null } \\
\text { hypothesis is rejected at 1\% level. This } \\
\text { shows that Customer satisfaction } \\
\text { develops Purchase intention towards } \\
\text { Smart Phone products by 53.6\%. }\end{array}$ \\
\hline
\end{tabular}

** Significant at $1 \%$ level

\section{SUGGESSTIONS AND CONCLUSION}

India has grown rapidly in smart phone market and also announced various liberal policies to meet the consumer demand. Of late, the tele-communication industry plays a leading role in job providers and employment generators in India. As per the report of Randstad India, the telecommunication industry will create over four million direct and indirect jobs in the forthcoming years. Internet usage in smart phones enhances sales in smart phone market; the government also takes necessary steps and put forth the efforts to develop technology in rural regions. The IDC pointed out Indian market will exceed the US smart phone market in the forth coming years. Low price smart phones and their life period are the major reasons for the accelerating growth of Indian smart phone market. The decision of Indian economy is always cost oriented, and also selling the product at reasonable rate. After 2012 the sale of smart phone market

is very high in India. Every smart phone producers are ready to offer budgeted smart phones with good sales deal to increase the sales. Mostly low cost smart phones quickly moving in the market and it also leads to improve consumer base marketing. In the modern scenario, we can see most of the smart phones moving in India with high discount deals through online marketing. Festival offers, Aadi sales, opening offers, seasonal sale and low cost phone with less EMI are the major factor which influences lower middle class consumers to buy the smart phones. Recently, smart phone advertisements create greater impact on buying intention of consumers in the market. Smart phones rendering enormous services through different apps. This apps supports to the consumers for food supply, booking cabs and online shopping. Mostly educated middle class people using these facilities. After the existence of $4 \mathrm{G}$, the sales of smart phones have been touched a great high. In India the modern technological development will make a tremendous impact in 2025 and it may promote 700 million Internet users. There is also a scope for telecom market to touch Rs. 10 trillion. The government also facilitates WIFI to 5,50,000 villages by March 2019 and planned policies for future India. The government also formed 5G India 2020 Forum to uplift the Indian economy. There are numerous brands in smart phone and often new models are coming up. The innovation of smart phone models and buying intention of consumers ensure hectic competition among new, upcoming and existing brands in the market. The Indian smart phone industry introducing innovative brands and also gives opportunity to already existing products. Recently, smart mobiles are available to all cadres of economic people and these budget phones promote greater impact among educated middle class. Smart phone industry supplies plethora of brands and gives more space to educated middle class consumers. On the other hand, smart phone industry distributes costlier model of smart phones to gain popularity among consumer market. Of course, it is not too hard for India to become an efficient leading market in smart phone industry. 


\section{Purchase Intention of Consumers Towards Smart Phones in Thiruvallur District}

In the forth coming years we can see the smart workers with smart phones and it is a time to make a digital India.

\section{REFERENCES}

1. Aakar,E., \& Nasir,V.A.,(2015) A review on consumers online purchase, Journal of Customer Behaviour, 14 (3),218-225.

2. Bringula,R.P (2016), Reasons for non-engagement of on-line shopping, International Journal of e-business research, 12(2), 29-30

3. Whitlark, Geurts and Swenson (1993) Bias and variability in Purchase Intention Scales, Journal of the Academy of Marketing Science,622-623

4. Tharmi and Senthilnathan, Samitham (2012), The Relationship of Brand Equty to Purchase Intention , IUP Journal of Marketing Management, May2012.

5. Anosh Muhammad, Naqvi Hamad and Ghulam Shabir, Impact of Brand Equity Drivers on Purchase Intention -A Quantitative Study on Smart Phone Market, IJIRD, Vol 3 Issue 5, Page 390, May 2014.

6. Ling,K.C.,Chai,L.T., \& piew T.H (2010), The effects of shopping orientations, online trust and prior online purchase experience towards customers online purchase intention, IBR 3(3), 65.

\section{AUTHOR PROFILE}

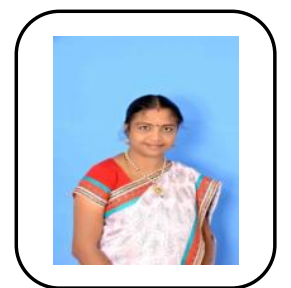

Dr.S.Sangeetha, working as Assistant Professor of Post Graduate Department of Commerce in Pachaiyappa's College. Chennai-600 030. She has 15 years of experience in UG and PG. .She has completed her B.Com (2000) and M.Com (2002) in Jaya College of Arts \& Science, Thiruninravur affiliated to university of Madras. She pursued her full time Ph.D in Commerce (Awarded on 22nd January 2007) in The New College, Chennai-600 014. She has completed her M.B.A (Finance) in University of Madras in 2009. Further, she has finished her Ph.D in Management (Awarded on 18th June 2018) in Bharathiar University, Coimbatore. She is guiding Ph.D students as external supervisor in Bharathiar and Mother Teresa University. At present she has produced $6 \mathrm{Ph} . \mathrm{D}$ scholars in Commerce and 2 Scholars pursuing Ph.D under her guidance. She published 14 papers in National and 7 papers inInternational Journal. She also published papers in Scopus and UGC CARE Listed Journals. She successfully published 2 books in Financial Services (ISBN NUMBER 978-81-920486-4-2) and Entrepreneurial Development (ISBN NUMBER 978-93-84634-99-5)for B.Com, B.B.M and B.B.A students as per Madras University syllabus. She is an Orator and Debater participating in many seminar events and TV programmes. She received plethora of awards and prizes for Tamil speech and poems.. 